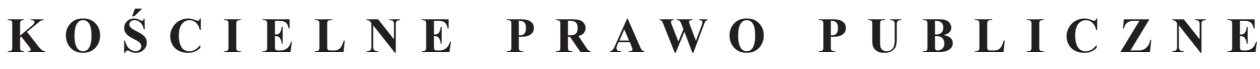

KOŚCIÓŁ I PRAWO 9(22) 2020, nr 1, s. 65-81

DOI: https://doi.org/10.18290/kip2091-4

\author{
Oleksandr Bilash \\ Tetyana Karabin
}

\section{TAXATION OF RELIGIOUS ORGANIZATIONS IN UKRAINE}

The issue of taxation of religious organizations is always relevant and often controversial. At the global level, it is recognized and accepted that states can provide certain benefits to religious communities and organizations, such as tax exemptions, financial subsidies, financial deductions from tax payments for the benefit of religious communities, or the use of state media resources. At the same time, if the state decides to ensure the separate legal status of religious organizations, the principles of equality and non-discrimination must be taken into account. ${ }^{1}$

On the one hand, the moral and ethical issues of state taxation of religious organizations continuetorise in Ukraine [Pysmennyy 2015, 73-79], and on the other hand, the state policy on providing benefits to non-profit religious organizations is not always positively reflected in society, especially in its crisis periods. For example, at present, the petition № 22/093062-ep "To Introduce Taxation for Religious Organizations and Churches" is reg-

Oleksandr Bilash, Ph.D. - Department of Administrative, Financial and Information Law, Uzhhorod National University; Kapitulna st. 26, 88000 Uzhhorod, Ukraine; e-mail: oleksandr.bilash@uzhnu.edu.ua; https://orcid.org/0000-0002-1248-7798

Tetyana Karabin, hab. Ph.D. - Department of Administrative, Financial and Information Law, Uzhhorod National University; Kapitulna st. 26, 88000 Uzhhorod, Ukraine; e-mail: tetyana.karabin@uzhnu.edu.ua; https://orcid.org/0000-0002-6538-5269

${ }^{1}$ Report A/HRC/19/60 of the Special Rapporteur on freedom of religion or belief. United Nations General Assembly (22.12.2011), https:/www.ohchr.org/Documents/HRBodies/HRCouncil/RegularSession/Session19/A-HRC-19-60_en.pdf [accessed: 30.05.2020]. 
istered on the website of the President of Ukraine, and signatures are being collected. ${ }^{2}$ Its content is reduced to the proposal for the time of the pandemic to abolish benefits and consider the introduction of taxation for churches and religious organizations with land and property taxes, income taxes, and so on.

At the same time, of course, a clear answer to the question of the expediency or inexpediency of granting benefits should be preceded by an objective analysis of the place of these benefits in the tax system of the state, their scope and procedure. Besides, the subject side is also an important question: who is or can be a taxpayer and a bearer of benefits.

\section{TERMINOLOGICAL ISSUES}

The basic law in Ukraine, which defines the responsibilities of the state concerning religious organizations and religious organizations to the state and society, is the Law "On Freedom of Conscience and Religious Organizations." 3 Following its provisions, religious organizations are religious communities, offices and centers, monasteries, religious fraternities, missionary societies (missions), theological educational institutions, and associations consisting of the above-mentioned religious organizations (Art. 7). The above-mentioned normative list is exhaustive. At the same time, according to Part 2 of Art. 23 of this law, religious organizations have the right to carry out charitable activities and charity both independently and through other structures formed by them, for example, charitable foundations, organizations, enterprises that are not religious organizations. It should be noted, an important area of the charitable activity of religious organizations is the provision of appropriate assistance not only to citizens outside of such organizations, but also to members of the same religious organizations, which is also important in determining possible tax benefits.

In this context, it is worth touching on the very concept of a "religious organization" and its legal significance. This concept has been the subject

${ }^{2}$ Vvesty opodatkuvannya dlya relihiynykh orhanizatsiy i tserkov [Introduce taxation for religious organizations and churches]. Petition № 22/093062-ep of 16.04.2020, https:// petition.president.gov.ua/petition/93062 [accessed: 30.05.2020].

${ }^{3}$ On Freedom of Conscience and Religious Organizations, Law of Ukraine № 987-XII of 23.04.1991, https://zakon.rada.gov.ua/laws/show/987-12 [accessed: 30.05.2020]. 
of scientific research, analysis and comparison with related concepts, in particular, "religious organization," "church" and "business entity" [Bochkov 2016, 76-80], "religious organization" and "church" [Kryvenko 2006, 130-32], "religious organization," "religious institution" [Payda 2018, 68-76], as well as a number of linguistic studies [Vorona 2016, 14-16]. However, domestic doctrine in most cases uses legislative provisions for analysis.

The normative recognition of the existence of religious organizations in Ukraine is carried out at the level of the basic law. Art. 35 of the Constitution of Ukraine stipulates that the church and religious organizations in Ukraine are separated from the state, and the school is separated from the church. ${ }^{4}$ However, a clear substantive separation of religious organizations from other legal entities of private law is carried out by the Law "On Freedom of Conscience and Religious Organizations," and based on activity performance. Thus, religious organizations are formed to meet the religious needs of citizens to profess and spread the faith and act following their hierarchical and institutional structure, elect, appoint and replace staff under their statutes (regulations) (Part 1 of Art. 7). Belonging or non-belonging to religious organizations determines the content of the constituent documents of the subjects, in particular, their statutes, as well as the procedure for state registration of legal entities and their termination. ${ }^{5}$

At the same time, the norms of tax legislation do not use the concept of a "religious organization," and for tax purposes the law introduced the term "non-profit organization." Basically, the system of tax benefits of a religious organization relates to obtaining the status of a non-profit organization. It should also be noted that in terms of terminology, the positions of scholars are sometimes different from the legislator, and along with the concept of "non-profit organizations" there are terms "non-commercial organizations," "non-commercial entities," "non-profit commercial entities," "non-profit associations," etc. in a similar sense [Bardashevych 2011, 20-21].

Thus, following the provisions of Art. 133.4.1. of the Tax Code, non-profit enterprises, institutions and organizations are those that simultaneously meet all the following requirements:

\footnotetext{
${ }^{4}$ Constitution of Ukraine of 28.06.1996, https://zakon.rada.gov.ua/laws/show/254K/96Bp [accessed: 25.05.2020].

${ }^{5}$ The provisions of Art. 12 of the Law "On Freedom of Conscience and Religious Organizations" determine the content and structure of the statutes of religious organizations, and Art. 14 of the same law defines their registration.
} 
1) Formation and registration are carried out in the manner prescribed by the law regulating the activities of the relevant non-profit organization. In our case, it is, first of all, the Law "On Freedom of Conscience and Religious Organizations." However, if religious organizations form other structures, such as enterprises, institutions and establishments that are not religious organizations, then, of course, the laws regulating those activities will be different, such as "On Charitable Activities and Charitable Organizations," 6 "Commercial Code of Ukraine," 7 etc.

It should also be noted that the constituent documents of such an organization should not include the reference to a specific law under which it was established as a mandatory requirement for inclusion of such an organization in the register of non-profit institutions and organizations. It is on this occasion that the State Fiscal Service of Ukraine issued in 2017 an individual tax consultation "On Religious Non-Profit Organizations," where the relevant provision is enshrined.

2) The constituent documents of such an organization must contain a prohibition on the distribution of income and profits or part thereof among the founders and participants.

3) The constituent documents of such an organization must regulate the transfer of assets to one or more non-profit organizations or crediting to the budget revenue in the case of termination of the legal entity.

4) Such an organization must be included in the Register of non-profit institutions and organizations. Such a register in Ukraine is an automated system for collecting, accumulating and processing data on non-profit enterprises, institutions and organizations, where information is entered by the State Tax Service of Ukraine. Non-profit organizations are only legal entities, and separate divisions of such non-profit organizations without the status of a legal entity are not subject to separate inclusion in the register.

Accordingly, the sign of non-profitability is assigned not only to religious organizations, but also to several other groups of enterprises, institutions

${ }^{6}$ On Charitable Activities and Charitable Organizations: Law of Ukraine № 5073-VI of 5.07.2012, https://zakon.rada.gov.ua/laws/show/5073-17 [accessed: 20.05.2020].

${ }^{7}$ Commercial Code of Ukraine, № 436 -IV of 16.01 .2003 , https://zakon.rada.gov.ua/laws/ show/436-15 [accessed: 25.05.2020].

${ }^{8}$ Regarding religious non-profit organizations: State Fiscal Service of Ukraine. Individual tax advice N 360/6/99-99-15-02-02-15/ipk of 25.05.2017, https://ips.ligazakon. net/document/PK070 [accessed: 24.05.2020]. 
and organizations. Thus, according to the Procedure for maintaining the Register of non-profit institutions and organizations, the assignment codes are from 0031 to 0048 , which provides a separate position for budgetary institutions, public associations, political parties, creative unions, pension funds, charities, unions and religious organizations including code $0035 .^{9}$ However, this list is not completed, as code 0048 corresponds to the meaning of "other legal entities whose activities meet the requirements established for non-profit organizations."

Thus, for a comprehensive and in-depth investigation of the peculiarities of taxation of institutions aimed at public non-profit activities in the religious sphere, it is necessary not to limit the analysis to religious organizations: religious communities, centers, monasteries, fraternities, etc. The range of permitted forms of the collective activity of religious organizations is wider. These religious organizations can form legal entities of private law to carry out charitable activities and clemency and to promote the statutory goals of the religious organization itself. Therefore, in the context of the subject of this article, the investigation of the peculiarities of the taxation of the latter is very important, taking into account that the activities of such organizations are non-profit.

\section{FEATURES OF TAXATION OF ENTERPRISE INCOME TAX}

According to the general provisions of the Tax Code of Ukraine, the object of income tax is income with a source of origin both from Ukraine and abroad (Art. 134 of the Tax Code), and the basic tax rate is 18 percent.

However, there is a benefit for non-profit enterprises, institutions and organizations to pay this tax - such legal entities are not payers of this tax, i.e. are exempt in full. Accordingly, if a religious organization or structure formed by it is registered as a non-profit organization, it is subject to legislative benefits. In general, a non-profit organization is not a type of

\footnotetext{
${ }^{9}$ On approval of the Procedure for maintaining the Register of non-profit institutions and organizations, inclusion of non-profit enterprises, institutions and organizations in the Register and exclusion from the Register: Resolution of the Cabinet of Ministers of Ukraine, № 440 of 13.07.2016, https://zakon.rada.gov.ua/laws/show/440-2016-п [accessed: 26.05.2020].
} 
enterprise, institution or organization, but a tax status that is assigned by the tax authorities by entering in a separate register.

At the same time, it is worth paying attention to the following points concerning religious organizations.

Firstly, a non-profit organization, by definition, cannot distribute income or profits among the founders and members of such an organization, as well as employees. Revenues or profits of a non-profit organization under Art. 133.4.2. of the Tax Code of Ukraine should be used exclusively to finance expenditures for the maintenance of the organization, the implementation of the purpose, goals, objectives and activities defined by its constituent documents. ${ }^{10}$ However, concerning religious organizations, such a provision is not unequivocally acceptable because they do charity work mainly among their members at the expense of income. In this case, according to the tax law, religious organizations cannot be recognized as non-profit.

These legislative provisions have caused a lot of controversy among scholars [Shpomer and Shvanska 2017, 21] and legal practitioners [Vasin 2016]. They directly contradicted the provisions of Part 7 of Art. 18 of the Law of Ukraine "On Freedom of Conscience and Religious Organizations," which stipulates that financial and property donations, as well as other income of religious organizations, are not taxed.

Such a collision was eliminated by amending the Tax Code of Ukraine in 2016 , when para. 2 was added to this problematic article. Its content is reduced to the fact that it is not considered the distribution of profits by a religious organization to use its income for non-profit activities, including humanitarian aid, charitable activities, clemency. ${ }^{11}$ These provisions enabled religious organizations to carry out the charitable activities provided for them by law in the interests of their members, including the provision of humanitarian aid, charitable activities, and clemency. At the same time, such legislative provisions are regarded by some researchers as direct state intervention in the financial activities of religious organizations [Shytyy 2016, 119], although we have not found grounds for this.

${ }^{10}$ Tax Code of Ukraine, Law № 2755-VI of 2.12.2010, https://zakon.rada.gov.ua/laws/ show/2755-17 [accessed: 25.05.2020].

${ }^{11}$ On Amendments to the Tax Code of Ukraine to Clarify Certain Provisions on Taxation of Non-Profit Organizations, Law of Ukraine № 1667-VIII of 6.10.2016, https:// zakon.rada.gov.ua/laws/show/1667-19 [accessed: 26.05.2020]. 
And to conclude the consideration of the issue of exemption from taxation of financial and property donations received by religious organizations in Ukraine, it is worth paying attention to the study of the problems of accounting for such donations. We fully agree with the position that proper legal regulation of taxation should be accompanied by the development and practical adaptation of methods of accounting for diocesan contributions and property (including icons, church utensils) owned by a religious organization [Vysochan 2018, 156].

Secondly, non-profit organizations, including religious organizations, are not prohibited from using the labor of employees who are paid wages and from whom personal income tax and military duty are deducted. However, in terms of corporate income tax, it should be noted that the funds directed to the remuneration of employees and the calculation of a single social contribution are not considered income distributed among members of the organization.

What is also very important is that the tax authorities also allow the possibility of distribution of part of the income of a non-profit organization among the members of such an organization based on civil law agreements. This is evidenced by the letters of the State Fiscal Service, which also emphasize the requirement that such costs should be financing the costs of their maintenance, implementation of goals (objectives, tasks) and activities defined by the constituent documents of such a non-profit organization. ${ }^{12}$

Thirdly, following the provisions of Art. 112 of the Commercial Code of Ukraine $^{13}$ and Art. 19 of the Law "On Freedom of Conscience and Religious Organizations" religious organizations have the right to establish publishing, printing, production, restoration and construction, agricultural and other enterprises necessary to ensure the activities of these organizations and perform their statutory tasks. The enterprise of a religious organization

${ }^{12}$ Letter № 28/6/99-99-15-02-02-15 from the State Fiscal Service of Ukraine of 4.01.2017, http://sfs.gov.ua/baneryi/podatkovi-konsultatsii/konsultatsii-dlya-yuridichnihosib/70982.html [accessed: 26.05.2020]; Letter № 2114/6/99-99-15-02-02-15 from the State Fiscal Service of Ukraine of 6.02.2017, http://sfs.gov.ua/baneryi/podatkovi-konsultatsii/ konsultatsii-dlya-yuridichnih-osib/71297.html [accessed: 26.05.2020]; Letter № 2422/L/9999-15-02-02-14 from the State Fiscal Service of Ukraine of 17.02.2017, http://sfs.gov.ua/ baneryi/podatkovi-konsultatsii/konsultatsii-dlya-fizichnih-osib/71421.html [accessed: 26.05.2020].

${ }^{13}$ Commercial Code of Ukraine: Law № 436-IV of 16.01.2003, https://zakon.rada.gov. ua/laws/show/436-15 [accessed: 28.05.2020]. 
is a unitary enterprise based on the property of a religious organization, operates based on the statute and is a legal entity.

Enterprises set up by religious organizations are non-profit entities whose main purpose is not to make a profit. They are formed to ensure the main activities of a religious organization: concerning the latter perform ancillary functions [Bardashevych 2011, 362]. That is why it is considered necessary to distinguish between the commercial activities of religious organizations directly and the economic activities of enterprises created by them.

The Law "On Freedom of Conscience and Religious Organizations" uses the term "production and economic activity" to refer to such activities, while the Commercial Code in this context uses the general term "economic activity." This discrepancy in terminology has led to various discussions in the scientific literature [Borysova 2014]. Thus, a proposal was made to change the name of Art. 19 of the Law "On Freedom of Conscience and Religious Organizations" from "Production and economic activities of religious organizations" to "Entrepreneurial activities of religious organizations" [Piddubna $2004,114]$ and making appropriate changes to its content. It is also proposed to introduce the concept of "religious activity" (cult and non-cult), where the commercial activity of religious organizations will be defined as extracurricular activities of religious organizations in the field of social production, aimed at manufacturing and selling products, performing works or providing valuable services of certaincost frames [Bochkov 2017, 73].

However, in our opinion, the proposed changes are not appropriate. After all, following the provisions of the Commercial Code, commercial activity carried out for profit isentrepreneurship, and that carried out without the purpose of profit - non-commercial economic activity (Part 2 of Art. 2). Art. 52 of the same code stipulates that non-commercial management is an independent systematic economic activity carried out by economic entities aimed at achieving commercial, social and other results without the purpose of making a profit.

Accordingly, since economic activities carried out by economic entities formed by religious organizations are aimed at achieving such goals, they fall under the characteristics of non-profit activities within the meaning of the Commercial Code and non-profit activities within the meaning of tax law. If such activity does not meet the statutory objectives and is aimed at making a profit and distributing it among the participants - such activity is entrepreneurial and taxable in the general order. 
In this context, it should be noted that the classification of organizational and legal forms of management in Ukraine does not quite correspond to the classification codes based on non-profit. Thus, the Classifier defines such types of organizational and legal forms of management for religious organizations as the enterprise of a religious organization (code 180); organization (institution) of a religious organization (code 440); religious organization (code 825). ${ }^{14}$ The register of non-profit organizations provides for the code 0035, which corresponds to religious organizations, as already mentioned. Therefore, tax authorities to non-profit organizations under the appropriate code "religious organizations" can register not only religious organizations within the meaning of Art. 7 of the Law "On Freedom of Conscience and Religious Organizations," but also other organizational and legal forms of management. However, for such as an enterprise of a religious organization or an organization (institution, establishment) of a religious organization, the status of religious organizations is determined in each case separately based on the analysis of the provisions of the charter of such non-profit organization, its name and so on..$^{15}$

This, in our opinion, is not a problem, as noted in some studies, but for sure makes it difficult to obtain statistical information on the activities of such organizations [Il'chenko and Vechirko 2016, 223].

\section{FEATURES OF PROPERTY TAXATION}

The property law of religious organizations in Ukrainian was enshrined in 1991 with the adoption of the Law "On Freedom of Conscience and Religious Organizations." This law clearly defines that religious organizations own, use and dispose of property that belongs to them on the right of ownership (Part 1 of Art. 18). Also, religious organizations have the right to use for

\footnotetext{
${ }^{14}$ About the statement of national standards of Ukraine, the state classifiers of Ukraine, national changes to interstate standards: the State Committee for Technical Regulation and Consumer Policy of Ukraine Order № 97 of 28.05.2004, https://zakon. rada.gov.ua/rada/card/v0097609-04 [accessed: 27.05.2020].

${ }^{15}$ On the inclusion of religious organizations in the Register of non-profit institutions and organizations: Letter № 8196/7/99-99-12-03-06-17 of the SFS of Ukraine of 21.03.2018, http://sfs.gov.ua/zakonodavstvo/podatkove-zakonodavstvo/listi-dps/72867.html [accessed: 27.05.2020].
} 
their needs buildings and property provided to them on a contractual basis by state, public organizations or citizens (Part 1 of Art. 17).

However, researchers acknowledge that at present the capabilities of religious organizations in the private sphere have significantly expanded [Kryvenko 2019, 54], which is clearly a positive feature and at the same time sets additional requirements for the settlement of property issues. This applies, first of all, to property tax.

Following the provisions of Art. 265 of the Tax Code of Ukraine, the property tax consists of a tax on real estate other than land one, transport tax and land fees. In the context of the investigation of our issues, it is relevant to analyze only the real estate tax, other than land tax and land fees.

As a general rule, real estate taxpayers are individuals and legal entities that own residential and non-residential real estate. Accordingly, if the property is owned by a religious organization or an organization formed by a religious organization, it should pay such a payment. However, according to part 1 of Art. 266.2.2. of the Tax Code such there are not objects of taxation of real estate owned by religious organizations, the statutes (regulations) of which are registered in the manner prescribed by law, if such objects are used solely to ensure their statutory activities, including those in which activities charitable institutions founded by religious organizations (shelters, boarding schools, hospitals, etc.). This benefit does not apply to real estate in which production or commercial activities are carried out.

Thus, a religious organization may be a taxpayer of property other than land if it is property used by a religious organization or a charitable institution established by such an organization not for their statutory activities but for other purposes, such as business activities, the provision of property rent, etc.

Similar benefits apply to land fees. In particular, the Tax Code provides for the implementation of the principle of payment for land use in two forms: first, it is a land tax paid by landowners and regular users of the land of state or communal ownership, and, secondly, rent, which copes under the terms of the lease agreement for land plots of state or communal ownership provided for term use (Art. 14). Land tax rates are not set at the national level, but by the relevant local governments on whose territory the site is located.

The list of land plots that are not subject to land tax is determined by Art. 283 of the Tax Code, which includes land plots provided for construction 
and maintenance of religious and other buildings necessary for the activities of religious organizations of Ukraine, whose statutes (regulations) are registered in the statutory order (para. 283.1.8 of Art. 283).

Instead, the Tax Code does not provide for benefits for the payment of rent for communal land plots. Therefore, for religious organizations it was and is important to refer them to the subjects of the right of permanent use of land, due to: a) the desire to avoid additional costs associated with the registration of land ownership, b) the need to ensure the main activities of religious organizations in connection with the allocation of land under their buildings, and c) avoidance of additional costs associated with the payment of land use, in addition to paying land tax [Mak 2016, 115].

The list of entities that had the right to permanent use of land at the time of entry into force of the Land Code of Ukraine (2001) included only enterprises, institutions and organizations of state and communal ownership. However, over time, this list has become broader, in particular, according to the Law of Ukraine "On Amendments to Certain Legislative Acts of Ukraine on the Right of Religious Organizations to Permanent Use of Land," 16 this list also includes religious organizations of Ukraine, whose statutes (regulations) in the manner prescribed by law, exclusively for the construction and maintenance of religious and other buildings necessary to ensure their activities (Art. 92). ${ }^{17}$ Therefore, the land tax exemption can be applied both to lands that are owned and those that are in the permanent use of a religious organization.

The issue of maintaining or not preserving land tax benefits is also practically useful if the land plots are leased by the payer. An unequivocal answer to this question is provided by the Tax Code in Art. 284.3, which stipulates that legal entities (including religious organizations) that use land plots and lease them or separate buildings, structures (parts thereof) pay land tax for such land plots and land plots under such buildings (their parts) on general grounds, taking into account the adjacent territory.

Also in this context, for religious organizations located in the territory that is not under the control of Ukraine and annexed by Russia, the follow-

${ }^{16}$ On Amendments to Certain Legislative Acts of Ukraine Concerning the Right of Religious Organizations to Permanent Use of Land, Law of Ukraine № 875-VI of 15.01.2009, https://zakon.rada.gov.ua/laws/show/875-17 [accessed: 27.05.2020].

${ }^{17}$ Land Code of Ukraine, Law № 2768-III of 25.10.2001, https://zakon.rada.gov.ua/ laws/show/2768-14 [accessed: 27.05.2020]. 
ing may be significant. From May 14, 2014, no land fee is charged or paid for land plots located in the temporarily occupied territory and owned or used, including on lease terms, by individuals or legal entities. Instead, the amounts of land fees accrued and paid during this period are considered overpaid monetary obligations and are refundable (para. 38 of subsect. 10 of sect. XX of the Tax Code).

\section{FEATURES OF VALUE ADDED TAXATION}

In general, the value-added tax remains one of the most problematic in Ukraine to date. This is due to the complexity of its administration and a large number of payment benefits. One cannot but agree with scholars who believe that too wide a list of benefits for this tax in Ukraine has a destabilizing effect on the nature of socio-economic processes, distorts the country's tax system [Lyutyy, Dryha, and Petrenko 2005, 115]. However, the reform of value-added tax benefits does not mean its automatic elimination, so it is necessary to understand in more detail the content and amount of benefits provided by the legislator.

The general tax rate is $20 \%$. Religious organizations are among those entities that have benefits for its payment. In particular, following para. 197.1.9. of the Tax Code it exempts from taxation the provision of religious services, namely, baptism, church marriage, funeral, prayer, memorial service, consecration (apartments, cars, etc.), circumcision, first communion, bar-mitzvah (adulthood). Also, the same article is exempt from taxation of the supply of religious objects on a clearly defined list. ${ }^{18}$ The supply of goods within the meaning of Ukrainian tax law is any transfer of the right to dispose of goods as the owner, including the sale, exchange or gift of such goods.

\footnotetext{
${ }^{18}$ Candles, icons (images), crosses (vestments, funeral, altar, relics, holy water, priestly, with ornaments, etc.), rosaries, bedspreads (altar, funeral, etc.), medallions with religious symbols, incense, lamp oil, myrrh, lamps, incense burners, candlesticks (seven candlesticks, Easter three-candlesticks, etc.), shrouds, vestments of priests (shirts, undergarments, air, eagles, stykhar, skufi, mitres, kamilavki, etc.), wreaths, grammars, accessories for baptism (baptismal box), gifts, gift boxes (reliquaries), fonts, seals for prosphora, drops, copy, pods, bowls, saucers, stars, spoons, ladles, discos, floats, bells, organs, harmoniums, passing prayers, belt "living in help," mezuzahs, thales, tefillins (phylacteries), sculptural images of saints, banners, fans, matzah, proskura, wafers, liturgical literature (para. b of Art. 197.1.9 of the Tax Code of Ukraine).
} 
Thus, privileges are enjoyed by religious organizations for the provision of clearly defined services and the supply of items that have an exhaustive list and relate to the purpose and objectives of such an organization.

It should not be overlooked here that value-added tax is an indirect tax, the final and actual payer of which is the consumer of the service or the buyer of the goods. The question of substantiating the expediency of the existence of such benefits, which have a social meaning and are established based on the real level of prices and incomes of the population, lies in the interdisciplinary plane and deserves a separate study. We will not analyze this issue in depth. At the same time, European research on tax attitudes in a multicultural environment has found that direct democracy, citizen participation, and religiosity help to increase tax morale [Strielkowski and Č́belková 2015, 660], motivating and disciplining not only economic incentives but also social and psychological factors [Jun and Yoon 2018]. Therefore, the filling of the budget does not always depend on the lack of benefits. Sometimes it is more cost-effective for the population to perceive the tax system as fair, rational and appropriate than to abolish tax benefits.

In this context, it is also worth mentioning the position contained in the domestic special literature on this subject: "[...] according to its content, the exemption from value-added tax is provided for religious services, the provision of which is not of a commercial nature, but is associated with the specific mission of religious institutions - the observance of religious traditions. Funds paid for religious services can be seen as donations from parishioners, and donations have always been a source of maintenance for religious institutions separated from the state, not the state. Exemption from payment for religious services is not a privilege, but a fact that the state does not encroach on what does not rightfully belong to it" [Tymchenko $2014,10]$.

\section{TAXATION OF INDIVIDUAL INCOME TAX AND SINGLE SOCIAL CONTRIBUTION}

We briefly touched upon the issue of personal income tax in the article in the context of the analysis of the peculiarities of the payment of income tax by religious organizations. Thus, non-profit organizations, including religious organizations, are not prohibited from using the labor of employees (either under an employment contract or under civil law for the performance of 
work), who are charged wages. Accordingly, such employees withhold personal income tax on a general basis of $18 \%$ and military duty of $1.5 \%$, as well as on a general basis. Privileges for participants or employees of non-profit organizations, including religious organizations, have not been established.

In addition to the personal income tax, the hiring of employees entails the obligation to pay a single social contribution by the employer. ${ }^{19}$ Following the legal provisions, the payers of the single contribution are, in particular, enterprises, institutions and organizations, other legal entities, regardless of ownership, type of activity and management, which use the work of individuals under an employment contract (para. 1 of Part 1 of Art. 4 Law "On the Collection and Accounting of a Single Contribution to the Obligatory State Social Insurance"). The amount of the contribution is deducted from the salary accrued to each person for different types of payments (basic and additional salaries, incentive and compensation payments, etc.) and is $22 \%$.

Thus, the single contribution to the salaries of employees of non-profit organizations is accrued on a general basis, and the rules of the Part 5 of Art. 8 of the quoted law apply to non-profit organizations (including religious organizations) in full, as well as to other organizations. Also, the provisions of this act do not contain exceptions regarding the financial responsibility of such organizations and the disciplinary, administrative, civil or criminal liability of officials of such organizations for the relevant violations.

\section{CONCLUSIONS}

Religious organizations and the enterprises, institutions and establishments created by them in Ukraine, the purpose of which is a public nonprofit activity in the religious sphere, have certain tax benefits.

First of all, it concerns the corporate income tax. Religious organizations registered with the tax authorities as non-profit organizations are exempt

\footnotetext{
19 The single contribution to the obligatory state social insurance is a consolidated insurance contribution, which is collected in the system of obligatory state social insurance on a mandatory basis and on a regular basis in order to ensure protection in cases provided by law of the rights of insured persons to receive insurance payments (services) for the current types of compulsory state social insurance (Art. 1 of the Law of Ukraine "On collection and accounting of a single contribution to compulsory state social insurance").
} 
from paying such tax if such profits are used to achieve the statutory goals of the religious organization itself. This benefit is provided for all non-profit organizations, regardless of the field of activity: budgetary institutions, public associations, political parties, creative unions, pension funds, charitable organizations, trade unions, employers' organizations and others.

Secondly, the property taxation of religious organizations has its peculiarities. Religious organizations and the structures formed by them are entitled to benefits for the payment of land tax and property tax other than land, if such objects are used exclusively to ensure the statutory activities of the religious organization itself. The established benefits are not maintained when carrying out production, commercial activities or renting facilities.

Religious organizations also have tax benefits for value-added tax, however, the focus of these benefits also does not go beyond the content of social and religious activities of religious organizations.

All other budget-filling taxes, including those that perform important social functions (personal income tax, single social contribution) are paid by religious organizations on a general basis.

In this way, in our opinion, the Ukrainian legislation creates, on the one hand, appropriate conditions for religious organizations to carry out their tasks of providing social services to the population, and on the other hand, ensures the principle of equality and non-discrimination of different commercial subjects.

\section{REFERENCES}

Bardashevych, Nataliya A. 2011. Khozyaystvenno-pravovoe obespechenye deyatel'nosty relyhyoznykh orhanyzatsyy. Dysertatsiya na zdobuttya stupenya kandydata yurydychnykh nauk. Donets'kyy natsional'nyy universytet.

Bardashevych, Nataliya O. 2011. "Relihiyni orhanizatsiyi yak sub'yekty hospodars'koho prava." Visnyk Donets'koho natsional'noho universytetu 1, no. 2:361-64.

Bochkov, Pavlo V. 2016. "Relihiyna orhanizatsiya yak sotsial'na i pravova struktura. Sproba definityvnoho analizu." Naukovyy visnyk pryvatnoho ta publichnoho prava 5:76-80.

Bochkov, Pavlo V. 2017. "Hospodars'ka diyal'nist' relihiynykh orhanizatsiy yak riznovyd poza kul'tovoyi relihiynoyi diyal'nosti." Aktual'ni problemy vitchyznyanoyi yurysprudentsiyi 3:70-73.

Borysova, Valentyna. 2014. "Relihiyna orhanizatsiya - funktsional'nyy vyd nepidpryyemnyts'kykh orhanizatsiy." Pravo Ukrayiny 2:123-30.

Il'chenko, Lyudmyla B., and Ol'ha H. Vechirko. 2016. "Administruvannya splaty podatkiv neprybutkovymy orhanizatsiyamy." Visnyk Khmel'nyts'koho natsional'noho universytetu. Ekonomichni nauky 5, no. 1:220-23. 
Jun, Byung W., and Sung M. Yoon. 2018. "Taxpayer's Religiosity, Religion, and the Perceptions of Tax Equity: Case of South Korea." Religions 9:333.

Kryvenko, Yuriy V. 2006. "Shchodo spivvidnoshennya ponyat' «tserkva» ta "relihiyna orhanizatsiya»." Universytets'ki naukovi zapysky: chasopys Khmel'nyts'koho universytetu upravlinnya ta prav 2 (18): 130-32.

Kryvenko, Yuriy V. 2019. "Okremi pytannya shchodo prava vlasnosti na mayno relihiynykh orhanizatsiyi." Prykarpat.s'kyy yurydychnyy visnyk 1 (26): 54-57.

Lyutyy, Ihor O., Anatoliy B. Dryha, and Myhaylo O. Petrenko. 2005. Podatky na spozhyvannya $v$ ekonomitsi Ukrayiny. Kyiv: Znannya.

Mak, Liliya. 2016. "Postiyne korystuvannya zemleyu yak subinstytut zemel'noho prava Ukrayiny.” Visegrad Journal on Human Rights 3:113-18.

Payda, Yuriy YU. 2018. "Ponyatiyno-teoretychni osoblyvosti relihiynykh instytutsiy." Naukovyy visnyk L'vivs'koho derzhavnoho universytetu vnutrishnikh sprav 3:68-76.

Piddubna, Victoriya. 2004. "Shchodo spetsial'noyi pravozdatnosti relihiynykh orhanizatsiy." Pravo Ukrayiny 11:112-15.

Pys'mennyy, Vitaliy V. 2015. "Moral'no-etychni aspekty opodatkuvannya u khrystyyans'komu virovchenni." Nauka moloda 23:73-79.

Shpomer, Alla I., and Anastasiya O. Shvans'ka. 2017. "Relihiyni orhanizatsiyi yak sub'yekty nekomertsiynoyi hospodars'koyi diyal'nosti." Zhurnal skhidnoyevropeys'koho prava 39:18-23.

Shytyy Serhiy I. 2016. "Okremi pytannya opodatkuvannya relihiynykh orhanizatsiy v zakonodavstvi Ukrayiny i Yevropeys'koho Soyuzu." Naukovyy chasopys NPU imeni M. P. Drahomanova. Seriya Ekonomika i pravo 31:117-22.

Strielkowski, Wadim, and Inna Čábelková. 2015. "Religion, Culture, and Tax Evasion: Evidence from the Czech Republic." Religions 6:657-69.

Tymchenko, Olena M. 2014. "Fiskalni naslidky perehlyadu pilh z PDV." Aktualni problemy rozvytku ekonomiky rehionu 10:7-15.

Vasin, Maksym. 2016. "Podatkova pastka dlya relihiynykh orhanizatsiy. Relihiyno-informatsiyna sluzhba Ukrayiny.” https://risu.org.ua/ua/index/expert_thought/comments/63389/ [accessed: 10.05.2020].

Vorona, Ivanna I. 2016. "Kharakterystyka ukrayins'koyi tserkovno-relihiynoyi terminolohiyi." Naukovyy visnyk Mizhnarodnoho humanitarnoho universytetu. Seriya filolohiya 23, no. 1:14-16.

Vysochan, Ol'ha O. 2018. "Osoblyvosti obliku v relihiynykh orhanizatsiyakh." Naukovyy visnyk Khersons'koho derzhavnoho universytetu. Seriya Ekonomichni nauky 29, no. 2:153-57.

\section{Taxation of Religious Organizations in Ukraine}

\section{Summary}

This paper concerns the taxation of religious organizations, enterprises, as well as other institutions established by religious organizations in Ukraine. Both the benefits and tax relief have been investigated in the context of acquisition of non-profit status. It is related to securing the statutory activity of a religious organization in the field of property tax and value added tax. As a rule, religious organizations pay taxes to the state budget according to general rules. This applies to both personal income tax and 
corporate income tax, as well as social security contributions. On the one hand it creates appropriate conditions for religious organizations to carry out their tasks of providing social services and on the other hand, it provides the principle of equality and nondiscrimination of different commercial subjects.

Key words: religious organizations; taxes; tax benefits; non-profit organizations

\section{Opodatkowanie religijnych organizacji w Ukrainie}

\section{Streszczenie}

W artykule przeanalizowano właściwości opodatkowania organizacji religijnych, a także przedsiębiorstw, instytucji i zakładów, utworzonych przez organizacje religijne w Ukrainie. Zbadano ulgi związane z uzyskaniem statusu organizacji niedochodowej (odnośnie do podatku od dochodu), a także ulgi, które są związane z zabezpieczeniem działalności statutowej organizacji religijnej (odnośnie do podatku od majątku i podatku od kosztów dodanych). Ustalono, że najbardziej napełniające budżety podatki, które pełnią ważne funkcje społeczne (podatek od dochodów osób fizycznych, państwowe ubezpieczenie społeczne), organizacje religijne spłacają na zasadach ogólnych, co z jednej strony formuje odpowiednie warunki dla spełnienia przez te organizacje swoich zadań $\mathrm{z}$ realizacji usług socjalnych, a z innej, zabezpiecza zasadę równości i niedyskryminacji podmiotów gospodarczych.

Słowa kluczowe: organizacje religijne; podatki; ulgi podatkowe; organizacje non-profit

Informacje o Autorze: Dr Oleksandr Bilash - Katedra Prawa Administracyjnego, Finansowego i Informatycznego, Użhorodzki Uniwersytet Narodowy; adres do korespondencji: Kapitulna st. 26, 88000 Uzhhorod, Ukraina; e-mail: oleksandr.bilash@ uzhnu.edu.ua; https://orcid.org/0000-0002-1248-7798

Informacje o Autorze: Dr hab. Tetyana Karabin - Katedra Prawa Administracyjnego, Finansowego i Informatycznego, Użhorodzki Uniwersytet Narodowy; adres do korespondencji: Kapitulna st. 26, 88000 Uzhhorod, Ukraina; e-mail: tetyana.karabin@ uzhnu.edu.ua; https://orcid.org/0000-0002-6538-5269 